\title{
Erratum to: The Precarious Diasporas of Sikh and Ahmadiyya Generations
}

\author{
Michael Nijhawan
}

(C) The Editor(s) (if applicable) and The Author(s) 2016

M. Nijhawan, The Precarious Diasporas of Sikh and

Abmadiyya Generations, Religion and Global Migrations, DOI 10.1057/978-1-137-48854-1

$\overline{\text { DOI } 10.1057 / 978-1-137-48854-1 \_8}$

The original version of the book contained errors which have been corrected.

The updated original online version for this book can be found at DOI 10.1057/978-1-137-48854-1

(C) The Editor(s) (if applicable) and The Author(s) 2017

E1

M. Nijhawan, The Precarious Diasporas of Sikh and

Abmadiyya Generations, Religion and Global Migrations,

DOI 10.1057/978-1-137-48854-1_8 